\title{
Incorporating EFL websites in class: Bangladeshi teachers' perceptions
}

\author{
Nousin Laila Bristi \\ United International University, Bangladesh
}

\begin{abstract}
Incorporating Information-Technology in classes is revolutionizing English language teaching (ELT) practices. Since teachers are the key personnel, their attitudes towards the process determine its success. This study presents the results of a study investigating Bangladeshi university level English as a foreign language (EFL) teachers' perceptions of incorporating EFL websites in their classes. The findings revealed that private university teachers' have more positive attitude than public university teachers do. In addition, both private and public university teachers reported of logistic limitations and systematic complications in their respective institutions. Following this, the study proposes enhancing administrative collaborations, arranging teacher-student skill development programmes, and creating customized websites for Bangladeshi ELT contexts.
\end{abstract}

Keywords: EFL websites, Attitude, University English Teachers, Bangladesh

\section{Introduction}

In foreign language teaching, the Internet is considered to be an essential tool (Chong, 2000) which is literally revolutionizing the traditional classroom practices. The everexpandinginternet resources like blogging, chatting, online readingsand videos, and readymade lessons, etc. are bringing unprecedented benefits for both EFL teachers and learners (Aydin, 2014; Almurashi, 2016; Cai, 2013). The fusion of ICT in EFL classes is substantially influencing teachingand learning patterns and success rates (Lin, 1997).

With the economic growth and the present government's promise to build digital Bangladesh, the number of Internet users in Bangladesh is increasingrapidly. Presently, there are 87 million people in the countrywho are using the Internet (BTRC, 2018). The Internet plays key roles in social, financial, communicational, foreign affairs, and in educational sector of the country.

At present, in most private and many public universities in the country, EFL classes are facilitated with computers and multimedia projectors (Joher, 2014; Afrin 2014). Furthermore, at the moment, out of 160 million of the population, 150 million are using mobile Internet for their various needs (BTRC, 2018). Studies suggest that the use of the Internet on mobile can be an important way to learn English (Liu \& He, 2014).In this circumstance, accessing teaching materials from EFL websites in 
class either from computers or mobile phones may be considered a timely approach in Bangladeshi context.

Blending technology in the class can be possible and fruitful only when the teachers have a positive attitude towards it (Sanchez, Marcose, Gonzalez, \& GuanLin, 2012). Accordingly, the study presents the results of a qualitative study investigating Bangladeshi tertiary level teachers' perceptions ofusing EFL websites in class.

\section{Literature review}

Foreign language learning is a continuous and a lengthy process which requires innovation in teaching to lift learners' motivation in and outside the class. The modern day EFL teachers, immensely empowered to enhance innovation in teaching by ICT, are ableto introduce diverse and unconventional teaching approaches (Emhamed \& Krishnan, 2011).

Drigas and Charami (2014) points thatICT in language classes is particularly effective for developing the four language skills. Reading and listening to online resources help learners to develop their receptive language skills. Similarly, teaching writing through a web-based approach and speaking through online communication can reduce learners' anxiety and maximize learning outcomes.

Joshi and Kaur (2011) emphasizes that for adult learners it is appropriate to incorporate the Internet in EFL classes. The set materials like texts, downloaded or recorded materials may seem less attractive to them because adults are generally attracted by the authentic and updated contents, like news articles, articles on contemporary issues for reading practices, listening to authentic news and connecting with native speakers. Moreover, internet resources are boundless, and allow scopes for intercultural communication.
Recently the integration of ICT in EFL classes has become a major concern among teachers and researchers (Azmi, 2017). Especially the number of websites that offer EFL teaching and learning materials is rising rapidly. Some of these websites concentrate on one particular skill such as podcasts in English (https:// www.podcastsinenglish.com/) is used for developing listening skillwhile BBC Learning English (http://www.bbc.co.uk/ learningenglish/) focuses on all the four skills.Some of them offer materials that can be filtered according to the learners' proficiency levels and topics of interests, for instance, ReadWorks.org. (https:// www.readworks.org/ ). From this website, teachers can choose reading materials based on their genre, topic and learners' proficiency level.Students and teachers may access the prepared activities and check the answers online for example, Awl Academic Sub list (http:// www.englishvocabularyexercises.com/ AWL/). (For more such useful websites, please see the appendix.)

For some time now, researchers have beenproposing plans for website material based EFL classes.Chong (2000) stated that in such classes, the Internet will not replace the teacher. Teachers will work as the facilitators. He has proposed a four-stage lesson for Internet material based class. First, the learners simply communicate with one another using Internet in the class, then they will explore the Internet for collecting data, which means they do extensive reading. Next, they produce their own pieces of writing in their own homepages. Finally, they work in groups to develop a thesis by researching the Internet contents.Robertson (n.d.) proposed a website-based reading lesson. In the class, the learners compare news articles on a similar contemporary topic from different news websites. Then they create their own websites or compare their country's and native country's website. Before asking the 
students to do this, the teacher himself/ herself has to go through the websites.Thus, teachers may customize their own classes by choosing specific websites, contents and activities based on the teaching and learning goals.

Considering the significance of teachers' attitudes towards the incorporation of technology in EFL classes, numerous studies have been conducted investigating the attitudes of teachers to the use of ICT in classrooms. Teachers' positive attitude is the determinant of whether a technology will be integrated in the teaching or not (Gilakjani \& Leong, 2012; Mollaei \& Riasati, 2013). Moreover, it (positive attitude) regulatesthe extent of use of technology in class (Al-Zaiyideen, Mei \& Fook,2010) and innovation in teaching and how students will use technology for learning the language (Gilakjani \& Leong, 2012). Teachers' positive attitudes towards technology in education is crucial for tackling the anxiety in a technology oriented education system (Yuksel \& Kavanoz, 2011).

Abunowara (2014), and. Riasati, Allahyar and Tan (2012) stated that teachers' negative attitudes towards the use of technology hamper the incorporation of technology in the class. Teachers' attitudes towards the inclusion of technology in education can be changed by incorporating technology courses in the teacher development programmes (Abbott \& Faris, 2000).

Pardo and Tellez (2009) saidthat teachers have to continuously look for engaging and innovative teaching resources that can capture the motivation of the learners. As an EFL teacher, the researcher has observed that, because of the lack of variation and flexibility, the EFL course books used in universities in Bangladesh, often fail to motivate students to become independent learners. Moreover, as the same text is used for both teaching and learning purposes, it limits the learners' exposure to the language. Therefore, it is high time for Bangladeshi ELT practitioners grasped the potentials of EFL website resources for ingenious teaching.

In order to ensure quality education, in National ICT Policy 2009, the incorporation of ICT in all sectors of education has been included as a major undertaking of the present government with special focus on English (Ministry of Science and Information \& Communication Technology, 2009). Moreover, the policy specifically addresses the issues of extensive logistic developments and teacher trainings and incentives for effectively using ICT in education. Studies have shown that, the implementation of the policy is already on the go (Hasan, 2017; Imon, 2017; Karim, 2014). There have already been a good number of studies on the incorporation of CALL in EFL classes in Bangladesh (Afrin, 2014; Akter, 2012; Nila, 2013). However, research studies on Bangladeshi teachers' attitudes towards the use of ICT in the class are hard to find while researchers are considering teachers' positive attitudes as a major condition for successful integration of ICT in EFL contexts (Richards, 2006). Hence, it is imperative to investigate Bangladeshi EFL teachers' attitudes towards the inclusion of EFL websites in the class.

The study bears multifold significances. First of all, the study will raise awareness among teachers and inspire technological and professional development and confidence by encouraging them to use EFL websites in the class. This, in return, will have a positive impact on the learning outcomes.

Besides, the study, by drawing attention to importance of website based teaching, will stimulate the authorities to take executive steps in private universities and distinctly 
in public universities. As a result, the target of the present government to create techsavvy world-class manpower (Ministry of Science and Information \& Communication Technology, 2009) will go one more step ahead.

\section{Objectives of the study}

The aims of the study are (a) to find out the attitudes of the teachers towards the use of EFL websites as teaching tools, (b) to identify the factors that hinder the execution of it, and (c) suggest measures for effective English language teaching through positive attitude towards the inclusion of online materials in EFL classes.

\section{Research questions}

The study has explored the following questions.

1. What are Bangladeshi University teachers' perceptions of using EFL websites in the classroom?

2. Is there any problem in incorporating EFL websites in the classroom?

\section{Methods}

\section{Research design}

This study makes use of a phenomenological research design, which "describes the meaning for several individuals of their lived experiences of a concept or a phenomenon" (Creswell, 2007, p.57) with a focus "on the participants' perceptions of the event or situation" (Williams, 2007, p.69). So this research study is qualitative in nature in that it attempts to explore the university teachers' perceptions towards incorporating EFL websites in the class in Bangladesh.

\section{Research tool}

Research data were collected though semistructured interviews. The data were collected mainly based on eight interview questions related to the teachers' perceptions and problems regarding incorporation of EFL websites inclasses. Questions1-5 were mainly related to the teachers' attitudes towards using EFL websites as teaching tool and questions 6-8 were related to the possible problems in doing so (Appendix B).

\section{Participants}

The details of the five purposefully selected participants are given in the following table:

Table 1. Demography of the Participants

$\begin{array}{llc}\text { Participants } & \text { Affiliations } & \begin{array}{c}\text { Years of } \\ \text { Experience }\end{array} \\ \text { T1 } & \text { Public University } & 5 \\ \text { T2 } & \text { Public University } & 3 \\ \text { T3 } & \text { Private university } & 6 \\ \text { T4 } & \text { Private university } & 3.5 \\ \text { T5 } & \text { Private university } & 11\end{array}$

Five university teachers participated in the research. The teachers were numbered as $\mathrm{T} 1, \mathrm{~T} 2, \mathrm{~T} 3, \mathrm{~T} 4$, and $\mathrm{T} 5$ for the convenience in data analysis. T1 and T2 were from public universities and $\mathrm{T} 3, \mathrm{~T} 4$, and $\mathrm{T} 5$ were from private universities. The table also shows the level of experiences of the teachers.T2 and T4 are comparatively less experienced than $\mathrm{T} 1, \mathrm{~T} 3$, and $\mathrm{T} 5$.

\section{Data collection procedure}

Before taking the interviews, the respondents were contacted in person and through phone calls. The interviews were conducted in the suitable times confirmed 
by the participants. Interviews of T1, T2 and T3, who are staying far away, were taken through active Facebook chats while T4 and T5 were interviewed in a face-to-face mode. Each of the interview sessions took 20-30 minutes. Facebook interviews were then taken as screen shots for later analysis whereas the direct interviews were recorded on Samsung J5 phone model and transcribed later.

\section{Data analysis procedure}

In order to analyze interview data, fivestep approach to analyzing semi-structured interview data (Piercy, 2004)was followed. First, all the interviews were transcribed using Microsoft Word programme. Then the transcript of each interview was read carefully several timesand observations were written down beside each statement. Next, the statements and observations with a similar concept were compiled together which helped to find the emerging themes. After that, it was also examined if the participants' experience had any impact on their perceptions. Those observations and key words were also recorded beside previous observations. Finally, reviewing all the observations and key points, the major themes were identified. Issues that were insignificant to the themes were excluded at this point. Finally, the findings were presented through an organized narrative that was supported by selected statements of the interviewees and research literature(Navigating the Dissertation, n.d.).After the analysis was done, the major findings of the qualitative data were presented based on the major themes and their subthemes. The findings were presented following Khodabandelou et al. (2016)

\section{Findings}

Two major themes teachers' attitudes towards the incorporation of EFL websites in classes and problems of using websites in the class emerged from the interpretation of interview data. These themes are mainly supported by and developed from their subthemes. The findings are illustrated below:

\section{Teachers' attitudes towards incorporating EFL websites in the class}

Table 2. Teachers' attitudes towards incorporating EFL websites in class: major and subthemes

Teachers'attitudes towards incorporating EFL websites in the class

willingness to use EFL websites in the class

belief about the effectiveness of incorporating EFL websites in the class

As the table shows, the major themeis the teachers' attitudes towards using EFL website as teaching tools in their classes. The subthemes are willingness to use EFL websites in the class and belief about the effectiveness of incorporating EFL websites in thclass. The subthemes are discussed in detail below:

\section{Teachers' willingness to use EFL websites in class}

From the study, it became clear that Bangladeshi university teachers have already had the mental preparedness to accept EFL websites as a teaching tool just like traditional materials in their classes. T4 explained,

Along with the existing teaching materials any contemporary and constructive materials can be used in the class. As these EFL websites are rich with helpful activities, they can be integrated in the

$120 \quad$ Journal of NELTA, Vol 23 No. 1-2, December 2018 
classes. The integration will accelerate the learning process.

Even, considering the young generation's tremendous interest in ICT, using EFL websites in the class will be a fitting practice. This will enhance learners' motivation to a great extent.Regarding this T2 pointed out that,

The young generation is very much connected to the use of technology. At the same time the conventional classroom practices are undergoing a lot of changes. If teaching takes place through the use of online resources the learners will find it more engaging.

\section{Teachers' belief about the effectiveness of using EFL websites in the class}

The study revealed the teachers' strong positive belief about the effectiveness of website contents as teaching tools. The teachers mainly indicated that the websites materials are especially helpful for teaching speaking and listening to the Bangladeshi learners. In this regard, T1 stated,

Though a good number of reading and writing materials are available offline, listening and speaking materials are 'difficult to find'. Teachers can use the EFL websites in classes when the learners will practice listening by accessing activities from those websites.

In addition, the participants believe that the EFL websites will be much more useful than existing materials as there is much flexibility to choose materials according to the teaching and learning needs. This will heighten teaching and learning outcomes.T5 pronounced,

If a specific reading activity doesn't match the proficiency level of the learners or the personal interests of the learners, the teacher can find a suitable by using the filtering options provided by the websites. Also the websites have stimulating grammar activities that can easily capture the interest of the learners.

However, the study also found that despite having notably positive attitudes, the teachers are still not completely confident in adopting websites in their classes. They are concerned about classroom management challenges and lightened roles of the teacher. T5 pointed out,

The websites should not be too frequently used in classes. Teachers have to finish the syllabus while using websites regularly might hamper this. Teachers may make a combination of online and offline materials.

The findings indicate that Bangladeshi teachers are mentally ready to embrace EFL websites as teaching tools in their class. They are aware of and aspiring to adopt the trends of $21^{\text {st }}$ century language classes. It can be assumed that these positive attitudes to using the website contents will make it much easier for them to overcome the challenges involved in the process.

\section{Problems of incorporating EFL websites in the class}

Table 3. Problems of incorporating EFL websites in class: major and subthemes

Problems of incorporating EFL websites in the class

Lack of skills among teachers

Infrustructural deficiencies in universities

Table 3 presents the second major theme of the findings which is problems of 
incorporating EFL websites in the class. The two subthemes are lack of skills among teachers and infrastructural deficiencies in universities. The subthemes are elaborately analyzed below:

\section{Lack of skills among teachers}

The study observed that teachers from both public and private universities lack skills to use websites as teaching tool in their classes. The decoding of interview data in combination with the observation of their teaching experiences revealed that the senior professionals both in public and private universities were comparatively less skilled. T5, a private university faculty and the most experienced (11 years' experience) among the participants said that,

The faculty (T5) lacks adequate skill and knowledge to incorporate EFL websites in the class although the faculty often takes help from internet for teaching. There are needs to improve expertise in more advanced use of technology in EFL classes.

On the contrary, the junior teachers, belonging to the digital generation, are more confident about their expertise. T2, one of the less experienced (3.5 years' experience) participantsdescribed,

Knowing to use websites and internet contents for teaching is a basic skill of a $21^{\text {st }}$ century language teacher. And the faculty (T4) possesses adequate skill and confidence to conduct a class using EFL website.

\section{Infrastructural deficiencies in universities}

The study has found that the universities in Bangladesh lack adequate logistic supports necessary to incorporate EFL websites in classes. The problems are worse in public universities. T1, a public university teacher, reported,

The scopes for using this opportunity are absent in the faculty's university. In most of the classes there is no multimedia. Though there are internet facilities in some of the classes, the speed is disappointing.

Conversely, the facilities are greater in private universities and things are improving rapidly there. T3, a private university teacher strongly claimed that,

The institution has established satisfactory supports for using online contents in their classrooms.

The above discussion reflects the teachers' dissatisfaction about the obstacles in personal and organizational levels to incorporating EFL websites in the class. While teachers' positive attitudes may promote the initiative, these restrictions, unless addressed resultantly, will adversely affect the attitudes of the teachers.

\section{Discussion}

The findings of the study have strong connection with the literature. Bangladeshi university teachers are feeling positive about the effectiveness of the EFL website as a teaching tool. Thisis in compliance with the findings of Capan(2012), Al-Zaiyideen, Mei and Fook (2010) where Turkish and Jordanian EFL teachers were found to have strong positive attitudes towards the use of ICT in classes.

Albirini (2004), cited in Rodgers (1995), views that the positive attitude is when the teacher believes the technological integration will be useful and easy for them. The participants of current study also believe accessing online materials in the class will be more effective than traditional materials. 
The findings demonstrate Bangladeshi teachers' unwillingness to integrate website materials on a regular basis. Bangladeshi university EFL teachers also prefer to have a combination of offline and online contents in their classes. Chong (2000) has indicated that while integrating internet materials in language classes, it is very natural that it will be accompanied by some problems like, managing the resources and the lessons properly during the class. Also he considers the inclusion of internet resources will be a supplement for the existing practices instead of being a replacement of it.

The findings reveal the teachers' lack of competence in using websites in their class which is in compliance with the findings of Raman and Yamat (2014). The current study has also found the more experienced teachers to be less skilled. Their study has also found that the older teachers are less interested in and capable of using ICT in their class.

The research discovered that limited logistic support is one of the main barriers to the use of websites in the class. This is similar to the findings of Ghavifekr et al. (2016). In his study, the Malaysian teachers also reported of the lack of adequate resources as one of the major constrains to teaching with ICT.

The uniformity of the findings indicates that the EFL teachers in universities of Bangladesh have the full mental orientation to utilize EFL websites in the class. They are well informed that the approach will enable them to enhance learners' motivation and learning outcomes by overcoming limitations of offline materials. The similarity in the problems between Bangladeshi context and other countries' also refer to the fact that Bangladesh is not lagging far behind in realizing modern ambiance in the EFL class.

\section{Conclusion and implications}

The study gives a glimpse of the prospect of using EFL websites in classes of Bangladeshi universities. At the same time, it focuses on the possible hindrances that should be addressed properly. First, ICT facilities, such as computer, multimedia projectors, high speed internet connection, Open-access Wi-Fi in the language classrooms of both public and private universities have to be ensured. Second, in public universities authorities have to take this as a major concern and invest more on the infrastructural improvements for ICT based EFL teaching. In addition, until the facilities are available, the teachers may instruct their students to use their smartphones and mobile data for using EFL websites in classrooms. Similarly, until the physical facilities can be provided, the government should minimize the cost of mobile data so that both students and teachers feel motivated to use them. Furthermore, both the universities and the governmental bodies should arrange adequate training programs to enhance teachers' technological skills and confidence and motivation to use EFL websites in the class. Finally, teachers may enhance their own technological knowledge and ability through self-study from different online courses, attending online events or simply asking for relevant instructions in their browsers or their better fellows.

Further research studies have to be carried out to recognize the potentials of the approach from students' perspectives. The study can be conducted between a control group where the students will be taught with the traditional or offline materials and an experimental group where the learners will be taught using online materials from selected EFL websites. The two groups' attitudes to the instructional approach and performances before and after instructions 
will be compared to determine the possible success of the inclusion of EFL websites in the class.

In short, the study has produced encouraging results regarding Bangladeshi university teachers' stance on the issue.However, the potentials for getting the best out of EFL website-based class are encumbered by infrastructural incapacity, systematiccomplications and lack of expertise of the personnel involved. Bangladeshi EFL teachers' aspiration for adopting $21^{\text {st }}$ century teaching competencies coupled with the universities' and the governments supports will function as the key factor in the development of the whole nation.

\section{References}

Abbott, J. \& Faris, S. (2014). Integrating technology into preservice literacy instructions: A survey of elementary education students' attitudes toward computers. Journal of Research on Computing in Education, [online] 33(2), pp.170-193.Available at https:// www.tandfonline.com/doi/abs / $10.1080 / 08886504.2000 .10782306$ [Accessed 6 Aug. 2018].

Abunowara, A. (2014). Using Technology in EFL/ESL Classroom. International Journal of Humanities and Cultural Studies, [online] 1(2), pp.1-18. Available at: https:/ / www.ijhcs.com/ index.php/ijhcs/article/view / 29 [Accessed 6 Aug. 2018].

Afrin, N. (2014). Integrating computer assisted instruction in the EFL classroom of Bangladesh. IOSR Journal Of Humanities and Social Science, [online] 19(II), pp.69-75.Available at http://iosrjournals.org/iosr-jhss / papers/Vol19-issue11/Version-4/ L0191146975.pdf [Accessed 6 Aug. 2018].
Akhter, M. (2012). Computer assisted language teaching (CALT) in Bangladesh at tertiary level. Master of Arts. East West University.

Albirini, A. (2006). Teachers attitudes toward information and communication technologies: The case of Syrian EFL teachers. Computers $\mathcal{E}$ Education, [online] 47, pp.373-398. Available at http:// citeseerx.ist.psu. edu/viewdoc/download?doi=10.1.1. $462.8303 \&$ rep $=$ rep $1 \&$ ty $p e=p d f$ [Accessed 6 Aug. 2018].

Almurashi, W. (2016). The effective use of Youtube videos for teaching English language in classrooms as supplementary material at Taibah University in Alula. International Journal of English Language and Linguistics Research, [online] 4(3), pp.32-47.Available at http:// www.eajournals.org/wp-content/ uploads/The-Effective-Use-ofYoutube-Videos-for-TeachingEnglish-Language-in-Classrooms-asSupplementary-Material-at-TaibahUniversity-in-Alula.pdf [Accessed 6 Aug. 2018].

Alshenqeeti, H. (2018). Interviewing as a data collection method: A critical review. English Linguistics Research, [online] 3(1), pp.39-45. Available at http://www.sciedu.ca/journal/ index.php/elr/article/view / 4081 [Accessed 6 Aug. 2018].

Al-Zaidiyeen, N., Mei, L. \& Fook, F. (2010). Teachers' attitudes and levels of technology use in classrooms: The case of Jordan schools. International Education Studies, [online] 3(2), pp.211-218.Available at https:// pdfs.semanticscholar.org/fd4a/ f00f0165145b41720ea79540106d 2dcecbb3.pdf [Accessed 6 Aug. 2018]. 
Aydin, S. (2014).The use of blogs in learning English as a foreign language. Mevlana International Journal of Education, [online] 4(1), pp.244-259.Available at https:// files.eric.ed.gov/fulltext / ED545624.pdf [Accessed 6 Aug. 2018].

Azmi, N. (2017). The benefits of using ICT in the EFL classroom: From perceived utility to potential challenges. Journal of Educational and Social Research, [online] 7(1), pp.111-118.Available at https:/ / content.sciendo.com/view / journals/jesr/7/1/article-p111.xml [Accessed 6 Aug. 2018].

BTRC (2018). License E Statistics. [online] Bangladesh Telecommunication Regulatory Commission. Available at http://www.btrc.gov.bd/datastatistics [Accessed 6 Aug. 2018].

Cai, C. (2013). The impacts and educational implications of online reading for English language learners.Master of Education.University of Washington.

Capan, S. (2012).Teacher attitudes towards computer use in EFL classrooms. Frontiers of Language and Teaching, [online] 3, pp.248254.Available at https:// www . academia.edu / 2442327 / Teacher_Attitudes_towards_Computer_ Use_in_EFL_Classrooms [Accessed 6 Aug. 2018].

Chong, D. (2000). The practical considerations of the Internet in the EFL classroom. Multimedia-Assisted Language Learning, [online] 3(2), pp.935.Available at http:// kmjournal.bada.cc/wp-content/ u ploads / $2013 / 05 / 3-2-1 . p d f$ [Accessed 6 Aug. 2018].

Creswell, J.W. (2007). Qualitative inquiry and research design: Choosing among five approaches (2nd ed.). Thousand
Oaks, California: Sage Publications, Inc.

Drigas, A., \& Charami, F. (2018). ICTs in English learning and teaching. International Journal of Recent Contributions from Engineering, Science $\mathcal{E} I T$, [online] 2(4), pp.4-10.Available at http://online-journals.org/ index.php/i-jes/article/view / 4016 [Accessed 6 Aug. 2018].

Emhamed, E., \& Krishnan, D. (2011). Investigating Libyan teachers' attitude towards integrating technology in teaching English in Sebha secondary schools. Academic Research International, [online] 1(3), pp.182-192. Available at http:// www.savap.org.pk/journals/ARInt./ Vol.1(3)/2011(1.3-19).pdf [Accessed 6 Aug. 2018].

Ghavifekr, S., Kunjappan, T., Ramasamy, L., \& Anthony, A. (2016). Teaching and learning with ICT tools: Issues and challenges from teachers' perceptions. Malaysian Online Journal of Educational Technology, [online] 4(2), pp.38-57.Available at https:// files.eric.ed.gov/fulltext / EJ1096028.pdf [Accessed 6 Aug. 2018].

Gilakjani, A., \& Leong, L. (2012). EFL teachers' attitudes toward using computer technology in English language teaching. Theory and Practice in Language Studies, [online] 2(3), pp.630-636.Available at http:// www.academypublication.com/ issues/past/tpls/vol02/03/28.pdf [Accessed 6 Aug. 2018].

Hasan, Z. (2017). Introducing ICT in primary education. Dhaka Tribune. [online] Available at https:// www.dhakatribune.com/opinion/ 2017/12/09/introducing-ictprimary-education/ [Accessed 6 Aug. 2018]. 
Imon, M. (2017). ICT integration in secondary education in Bangladesh: A study of policy and practice. Master of Philosophy.University of Oslo.

Joher, U. (2018). CALL: The changing trends of language learning and teaching in private universities of Bangladesh. Bachelor of Arts. BRAC University.

Joshi, D., \& Kaur, G. (2011). Role of Internet in a language classroom. Journal of Technology for ELT, [online] 1(4). Available at https://sites.google. com/site/journaloftechnologyforelt/ archive/october2011/role-of-internet [Accessed 6 Aug. 2018].

Karim, M. (2014). IT/ICT plan for higher education of Bangladesh: A significant investigation on present goes policy and upcoming policy recommendation. Banglavision Journal, [online] 14(1), pp.34-40. Available at http://bv-f.org/VOL14/04.\%20BV\%20Final.pdf [Accessed 6 Aug. 2018].

Khodabandelou, R., et al. (2016). Exploring the main barriers of technology integration in the English language teaching classroom: A qualitative study. International Journal of Education $\mathcal{E}$ Literacy Studies, [online] 4(1), pp.5358.Available at https://files.eric.ed. gov / fulltext/EJ1149284.pdf [Accessed 6 Aug. 2018].

Lin, C. (1997). The internet and English language teaching. REACT, [online] 1, pp.22-28. Available at https:// repository.nie.edu.sg/bitstream/ 10497/3770/1/REACT-1997-1 22.pdf [Accessed 6 Aug. 2018].

Liu, Q., \& He, X. (2014). Using Mobile Apps to Facilitate English Learning for College Students in China. Bechelor's. University of Boras.
Ministry of Science and Information \& Communication Technology (2009). National ICT Policy - 2009. Government of the People's Republic of Bangladesh

Mollaei, F., \& Riasati, M. (2013).Teachers' perceptions of using technology in teaching EFL. International Journal of Applied Linguistics $\mathcal{E}$ English Literature, [online] 2(1), pp.13-22. Available at: http://www.journals. aiac.org.au/index.php/IJALEL/ article/view/817 [Accessed 6 Aug. 2018].

Nila, N. (2013). Implementation of CALL in the EFL classroom: Teachers' perspectives and attitudes in developing CALL-based classroom. Master of Arts. BRAC University.

Navigating the Dessertation. (n.d.). Presenting Findings (Qualitative) Topic 1: Chapter 4. [online] Available at http:/ / dissertationedd.usc.edu / presenting-findings-qualitative.html [Accessed 6 Aug. 2018].

Pardo, A., \& Téllez, M. (2009). ELT materials: The key to fostering effective teaching and learning settings. Profile: Issues in Teachers' Professional Development, [online] pp.171-186. Available at https:// revistas.unal.edu.co/index.php/ profile/article/view/11449/36802 [Accessed 6 Aug. 2018].

Piercy, K. (2004). Analysis of semi-structured interview data. [ebook] Available at http:// docplayer.net/13806485Analysis-of-semi-structuredinterview-data-kathleen-w-piercyutah-State-University-1.Html [aCCESSED 6 aUG. 2018].

Raman, K., \& Yamat, H. (2014). Barriers teachers face in integrating ICT during English lessons: A case study. The 
Malaysian Online Journal of Educational Technology, [online] 2(3), pp.11-19. Available at https:/ / files.eric.ed.gov/ fulltext/EJ1086402.pdf [Accessed 6

Riasati, M., \& Allahya, N. (2012).Technology in language education: Benefits and barriers. Journal of Education and Practice, [online] 3(5), pp.2530.Available at http:// www.iiste.org/Journals/index.php/ JEP/article/view/1495 [Accessed 6 Aug. 2018].

Richards, J. (2006). Materials development and research-Making the connection. Regional Language Centre Journal, [online] 37(1), pp.526.Available at http:// www.peterbeech.com/teta1053/ resources/richards_2006.pdf [Accessed 6 Aug. 2018].

Robertson, C. (n.d.). Using the Internet 2. [online] BBC Teaching English. Available at https:// www.teachingenglish.org.uk/article/ using-internet-2 [Accessed 6 Aug. 2018].

Sanchez, A., Marcose, J., Gonzalez, M., \& GuanLin, H. (2012).In-service teachers' attitude towards the use of ICT in the class. Procedia Social and Behvioral Sciences, [online] 46, pp.1358 - 1364. Available at https:// www.sciencedirect.com/science/ article/pii / S1877042812014310 [Accessed 6 Aug. 2018].

Williams, C. (2007). Research methods. Journal of Business and Economic Research, 5 (3), 65-72.

Yüksela, G., \& Kavanoz, S. (2011). In search of pre-service EFL certificate teachers' attitudes towards technology. Procedia Computer Science, [online] 3, pp.666-671. Available at https://www.sciencedirect.com/ $\mathrm{s}$ c i e n c e / a r t i c l e / p i i / S1877050910004862 [Accessed 6 Aug. 2018].

\section{Appendix A}

\section{Useful Websites}

A list of such useful websites along with their links is provided below:

Voice of America Special English: https:/ /learningenglish.voanews.com/

BBC Teaching English: https:// www.teachingenglish.org.uk/

Purdue Online Writing Lab:https:// owl.english.purdue.edu/owl/

On es top Englis h. com:ht t p: / / www.onestopenglish.com/

Ello:http:/ / www.elllo.org/

ESLgold:http:/ / eslgold.com/

Besides these the teachers can use many authentic online resources as teaching materials, like the following websites:

YouTube: https:/ /www.youtube.com/

The Readers' Digest:https:/ / www.rd.com/

The Daily Star :https://www.thedailystar. net/

Google Hangouts :https://hangouts. google.com/

And the list may go on and on as everyday more and more websites are getting added to the Internet. 


\section{Appendix B}

\section{Interview Questions}

1. Which tools and materials do you usually use in your language classroom?

2. Do you think the materials you use in your class are adequate for teaching all (reading, writing, speaking, listening) English Language skills?Why/why not?

3. Do you think using EFL websites in class can help you to overcome limitations of traditional teaching materials? How?

4. Do you think using these websites can make teaching more effective? How?

5. Do you think these websites should be regularly used in classroom? Why/why not?

6. Do you think there are enough facilities in your institution to use ELT websites in your classroom? Please explain.

7. Do you have enough skills and knowledge to effectively use ELT websites in your class? Please explain.

8. Any further opinion on the topic?

\section{Contributor}

Nousin Laila Bristi, an Assistant Professor in English at United International University, Dhaka, completed M.A. in Applied Linguistics and ELT from the department of English at University of Dhaka. She has already published three research articles in international journals. Her research interests are psycholinguistics, ELT and Technology in Education. 